OPEN ACCESS

Edited by:

Bradley Patton Dixon Children's Hospital Colorado,

United States

Reviewed by:

Licia Peruzzi,

Regina Margherita Hospital, Italy

Richard James Glassock,

UCLA David Geffen School of Medicine, United States Jonathan Barratt,

University of Leicester, United Kingdom

${ }^{*}$ Correspondence: Dana V. Rizk

drizk@uabmc.edu

Robert J. Wyat

rwyatt@uthsc.edu

Specialty section:

This article was submitted to

Autoimmune and Autoinflammatory

Disorders,

a section of the journal

Frontiers in Immunology

Received: 11 December 2018

Accepted: 25 February 2019

Published: 19 March 2019

Citation:

Rizk DV, Maillard N, Julian BA, Knoppova B, Green TJ, Novak J and Wyatt RJ (2019) The Emerging Role of Complement Proteins as a Target for

Therapy of IgA Nephropathy.

Front. Immunol. 10:504.

doi: 10.3389/fimmu.2019.00504

\section{The Emerging Role of Complement Proteins as a Target for Therapy of IgA Nephropathy}

\author{
Dana V. Rizk ${ }^{1 *}$, Nicolas Maillard ${ }^{2}$, Bruce A. Julian ${ }^{1}$, Barbora Knoppova ${ }^{3,4}$, Todd J. Green ${ }^{3}$, \\ Jan Novak ${ }^{3}$ and Robert J. Wyatt ${ }^{5 *}$ \\ ${ }^{1}$ Department of Medicine, University of Alabama at Birmingham, Birmingham, AL, United States, ${ }^{2}$ Department of \\ Nephrology, Dialysis, Transplantation, CHU de Saint-Etienne, GIMAP, EA3064, Université Jean Monnet, COMUE Université \\ de Lyon, Rhône-Alpes, France, ${ }^{3}$ Department of Microbiology, University of Alabama at Birmingham, Birmingham, AL, \\ United States, ${ }^{4}$ Department of Immunology, Faculty of Medicine and Dentistry, Palacky University and University Hospital, \\ Olomouc, Czechia, ${ }^{5}$ Department of Pediatrics, University of Tennessee Health Sciences Center, Memphis, TN, United States
}

IgA nephropathy (IgAN) is the most common form of primary glomerulonephritis worldwide and a common cause of end-stage renal disease. Evaluation of a kidney biopsy is necessary for diagnosis, with routine immunofluorescence microscopy revealing dominant or co-dominant IgA immunodeposits usually with complement C3 and sometimes IgG and/or IgM. IgA nephropathy reduces life expectancy by more than 10 years and leads to kidney failure in $20-40 \%$ of patients within 20 years of diagnosis. There is accumulating clinical, genetic, and biochemical evidence that complement plays an important role in the pathogenesis of $\lg A$ nephropathy. The presence of C3 differentiates the diagnosis of IgA nephropathy from the subclinical deposition of glomerular IgA. Markers for the activation of the alternative and mannan-binding lectin $(\mathrm{MBL})$ pathways in renal-biopsy specimens are associated with disease activity and portend a worse renal outcome. Complement proteins in the circulation have also been evaluated in IgA nephropathy and found to be of prognostic value. Recently, genetic studies have identified IgA nephropathy-associated loci. Within these loci are genes encoding products involved in complement regulation and interaction with immune complexes. Put together, these data identify the complement cascade as a rational treatment target for this chronic kidney disease. Recent case reports on the successful use of humanized anti-C5 monoclonal antibody eculizumab are consistent with this hypothesis, but a better understanding of the role of complement in IgA nephropathy is needed to guide future therapeutic interventions.

Keywords: complement, IgA nephropathy, alternative complement pathway, mannan binding lectin complement pathway, IgAN pathogenesis, IgAN, IgAN treatment

\section{INTRODUCTION}

IgA nephropathy (IgAN), initially described by Berger and Hinglais in 1968 (1), is the most common primary glomerulopathy in many countries. IgAN causes end-stage renal disease in $20-40 \%$ of the patients within 20 years after diagnosis (2), and reduces life expectancy by 10 years (3). The diagnosis is based on immunofluorescence- or immunohistochemical-microscopic examination showing IgA as the dominant or co-dominant immunoglobulin in the glomerular 
immunodeposits (4). These deposits may also contain IgG, IgM, or both (4). The IgA is exclusively of the IgA1 subclass (5). Complement component $\mathrm{C} 3$ is present in the same distribution as IgA in up to $90 \%$ of biopsies (4).

Recent studies have confirmed an autoimmune nature of IgAN. The most widely accepted mechanism for the pathophysiology of the disease entails four "hits" (Figure 1) (6). The first hit refers to increased levels of circulatory polymeric IgA1 with aberrant $O$-glycosylation of its hinge region. These molecules lack galactose in some $O$-glycans in the hinge region (galactose-deficient IgA1, Gd-IgA1), thus exposing $\mathrm{N}$ acetylgalactosamine (GalNAc) as terminal glycan. The second hit is the formation of glycan-specific IgG or IgA1 autoantibodies targeting terminal GalNAc-containing hinge region of Gd-IgA1 (7). The third hit is formation of circulating immune complexes comprising Gd-IgAl and IgG autoantibody. Other proteins can bind Gd-IgAl, such as the soluble Fca receptor (sCD89), to form complexes, although it is not clear whether such complexes would activate complement (8). Some of the circulating immune complexes pass through fenestrae in the glomerular capillaries to enter the mesangium where they may incite cellular proliferation of mesangial cells and overproduction of extracellular matrix, cytokines, and chemokines (hit four) that potentially lead to chronic kidney damage. This proposed multi-step process is consistent with the finding that glomerular IgA immunodeposits of patients with $\operatorname{IgAN}$ are enriched for $\operatorname{Gd}-\operatorname{IgA} 1(9,10)$ and $\operatorname{IgG}$ co-deposits are of IgG1 and IgG3 subclasses, as are the circulatory IgG autoantibodies specific for Gd-IgA1 $(7,11)$.

Key observations in kidney transplantation support the notion that kidneys in IgAN are damaged as innocent bystanders: IgAN frequently recurs in allografts, whereas IgA deposits clear from kidneys of donors with subclinical IgAN within a few weeks after implantation into non-IgAN recipients (12).

IgAN is broadly categorized as primary or secondary, i.e., associated with a systemic disease, be it an infectious, inflammatory, or autoimmune process (13). Within primary IgAN the spectrum of disease varies substantially. The clinical presentation differs between children and adults, and the disease severity as well as gender distribution across ethnic and racial backgrounds differ widely. IgAN can manifest without extra-renal involvement, or as part of a systemic vasculitis phenotype currently referred to as IgA vasculitis with nephritis (previously Henoch Schönlein pupura nephritis) (14). About $5-8 \%$ of patients have a first- or second-degree relative with biopsy-proven IgAN or urinary abnormalities suggesting a familial occurrence or genetic predisposition for the disease (15). All these observations raise the possibility that the renal pathology phenotype we call IgAN results from different pathophysiologic processes.

In recent years, mounting pathologic, biochemical, experimental, and genetic findings have supported a pivotal role of complement activation in disease onset and progression of IgAN. In particular, the alternative and mannan-binding lectin (MBL) pathways seem to be involved. These observations, in turn, have generated tremendous interest in targeting complement pathways as an approach to treatment.

\section{BRIEF OVERVIEW OF THE COMPLEMENT-ACTIVATION PATHWAYS}

Early knowledge of complement proteins stemmed from the 19th-century discovery of a heat-labile component of normal plasma that augmented the opsonization of bacteria by antibodies and enabled antibodies to kill some bacteria $(16,17)$. The name "complement" was derived from the description of the activity that "complemented" the antibacterial activity of antibodies. The complement system is an important link between innate and adaptive immunity as it participates in immunosurveillance and tissue homeostasis. The system consists of the activation cascade of $\sim 50$ proteins located in plasma, tissues, and cells (1820). Many of these complement-associated proteins have been described as proteases that are activated by proteolytic cleavage. This cascade of proteolytic events must be well-controlled for the system to work properly. A malfunction may result in immunodeficiency or autoimmune manifestations (21-23).

Classical, alternative, and lectin pathways are the three known ways of complement system activation (Figure 2). Each pathway has a different triggering mechanism; however, after creating the $\mathrm{C} 3$-activating enzymes ( $\mathrm{C} 3$ convertases), the pathways share the same sequence of events that culminates with assembly of the membrane-attack complex (MAC) (26). The first activated component of the classical pathway is $\mathrm{Clq}$ protein that recognizes an antigen-antibody (IgG or IgM) complex and subsequently binds its partners $\mathrm{C} 1 \mathrm{r}$ and $\mathrm{C} 1 \mathrm{~s}$ to create a protein complex named $\mathrm{C} 1$ ( $\left.\mathrm{C} 1 \mathrm{q}: \mathrm{C}_{2} \mathrm{r}_{2}: \mathrm{C}_{1} \mathrm{~s}_{2}\right)(27,28) . \mathrm{C} 1$ has the ability to cleave complement components $\mathrm{C} 2$ and $\mathrm{C} 4$, into $\mathrm{C} 2 \mathrm{a}$ and $\mathrm{C} 4 \mathrm{~b}$, respectively, that interact to form $\mathrm{C} 3$ convertase (C4b2a). Subsequently, the cleavage of component C3 by participation of C3 convertase produces two proteins. The smaller submit C3a is an anaphylatoxin that mediates inflammation. The larger subunit $\mathrm{C} 3 \mathrm{~b}$ is an opsonin that binds covalently through a reactive thioester bond to adjacent pathogen molecule and thereby targets it for destruction by phagocytes equipped with receptors for C3b. As the next step of the cascade, C5 convertase is formed by association of $\mathrm{C} 3 \mathrm{~b}$ with $\mathrm{C} 4 \mathrm{~b} 2 \mathrm{a}$ or with $\mathrm{C} 3 \mathrm{bBb}$ (the product of cleavage from the alternative pathway). $\mathrm{C} 5$ convertase then releases the $\mathrm{C} 5 \mathrm{a}$ subunit from $\mathrm{C} 5$ protein and the remaining $\mathrm{C} 5 \mathrm{~b}$ fragment initiates formation of the MAC. After the addition of components $\mathrm{C} 6, \mathrm{C} 7$, and $\mathrm{C} 8$, the complex C5b-8 is incorporated into the cell membrane, followed by addition of 10-16 units of C9 component that are arranged in the shape of ring, creating a pore in the membrane and leading to cell lysis and death. C3a and C5a cleavage products have inflammatory and chemo-attractant activities exerted through the corresponding $\mathrm{C} 3 \mathrm{a}$ and $\mathrm{C} 5 \mathrm{a}$ receptors. Moreover, complement functions include facilitation of uptake and destruction of pathogens by phagocytic cells through the specific recognition by complement receptors on phagocytes. There are six types of complement receptors: CR1-4, and C3a and C5a receptors $(29,30)$.

The alternative pathway is continuously activated at a low level, and is amplified on activating surfaces or in the fluid phase by bacteria, dying cells, and immune complexes. The spontaneous hydrolysis of a thioester bond in C3 component 


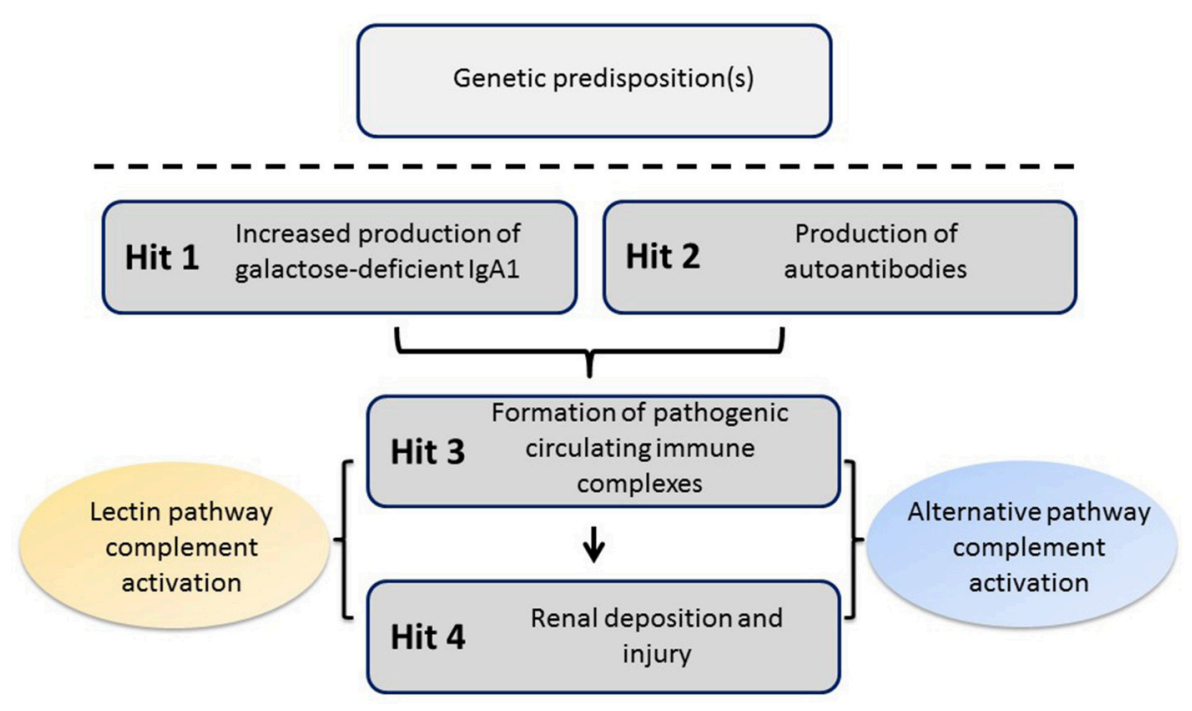

FIGURE 1 | Proposed four-hit pathogenesis of IgAN. Circulatory galactose-deficient IgA1 (Gd-lgA1) (Hit 1) is recognized by specific autoantibodies (Hit 2) to form circulating immune complexes (Hit 3). Some of these immune complexes deposit in the kidneys, thereby leading to mesangial activation, enhanced proliferation of mesangial cells, and ultimately kidney injury (Hit 4). Certain genetic loci have been associated with increased risk for developing lgAN. The activation of the alternative and, at least in some patients, mannan-binding lectin (MBL) pathways by immune complexes is involved in disease pathogenesis.

produces $\mathrm{C} 3 \mathrm{~b}\left(\mathrm{H}_{2} \mathrm{O}\right)$ that is tightly controlled by plasma regulatory proteins (factors $\mathrm{H}[\mathrm{FH}]$ and $\mathrm{I}[\mathrm{FI}]$; membrane cofactor protein [MCP, CD46]; complement receptor 1 [CR1, CD35]; decay accelerating factor [DAF, CD55]; and complement factor H-related proteins [CFHRs]) (31). Together, these regulators prevent the formation or enhance the dissociation of the alternative pathway $\mathrm{C} 3$ convertase (FH, CR1, and DAF) or serve as cofactors for FI-mediated inactivation of $\mathrm{C} 3 \mathrm{~b}$ to $\mathrm{iC} 3 \mathrm{~b}$ (FH, MCP, and CR1). CFHRs compete with FH. Properdin is a positive regulator of the alternative pathway, with its main role of stabilizing the alternative pathway C3 convertase (and C5 convertase). Active convertase $\mathrm{C} 3 \mathrm{bBb}$ acts similarly to $\mathrm{C} 4 \mathrm{~b} 2 \mathrm{a}$, as it activates C5 convertase that leads to formation of $\operatorname{MAC}(29,30)$.

The lectin pathway is stimulated upon binding of MBL with MBL-associated serine proteases (MASP) or ficolins to specific carbohydrate patterns. MASP-2 can also directly cleave C3 while bypassing the usual sequences to activate C4 and/or C2 (32).

Recent data have shown that renin, an aspartate protease produced by juxtaglomerular apparatus in the kidneys, can also function as a $\mathrm{C} 3$ convertase to activate the terminal portion of the complement cascade (33).

\section{ROLE OF COMPLEMENT PROTEINS IN IgAN}

Complement proteins are activated in IgAN. Immunohistochemical findings of $\mathrm{C} 3$, properdin, C4d, MBL and C5b-9 deposits in mesangium of IgAN biopsy samples, coupled with the general absence of $\mathrm{Clq}$, confirm activation of alternative and lectin pathways rather than classical pathway $(24,34,35)$.

The complement cascade is regulated at several levels to prevent unwanted (uncontrolled) activation. As noted above, one of the controlling steps of the alternative pathway relies on complement $\mathrm{FH}$ that is present in plasma and on tissue surfaces. It has two functions, stabilizing complexes with $\mathrm{C} 3 \mathrm{~b}$ and accelerating dissociation of C3bBb. CFHRs are sequentially similar to $\mathrm{FH}$ and can compete with $\mathrm{FH}$ for $\mathrm{C} 3 \mathrm{~b}$ binding. These proteins have been studied as possible risk factors of IgAN. In a study with 1,126 IgAN patients, higher circulating levels of CFHR-5 were associated with IgAN development and progression $(36,37)$. Another study showed that plasma levels of FH antagonists FHR-1 and the FHR-1/FH ratio were elevated in patients with IgAN and associated with disease progression, whereas the plasma level of FHR-5 and the FHR-5/FH ratio were not. However, elevated levels of FHR- 5 correlated with poor response to immunosuppressive therapy $(38,39)$. Moreover, gene deletions of CFHR1,3 (protective alleles) and some rare variants of CFHR5 are associated with IgAN susceptibility.

\section{Complement Activation by $\lg A$, IgG, IgM, and Immune Complexes}

Human IgG antibodies can have pro- and anti-inflammatory activities, depending on the engagement of $\mathrm{Fc} \gamma$ receptors and the activation of the complement system, which, in turn, depends on the IgG subclass, hexamerization, glycosylation, and antigen density (40-49). Activation of the classical pathway by IgG (and IgM) isotypes (mostly driven by IgM and IgG1 and IgG3 subclasses, and hexameric IgG) results in production of proinflammatory $\mathrm{C} 3 \mathrm{a}$ and $\mathrm{C} 5 \mathrm{a}(50)$. This process then triggers recruitment of effector cells wherein the deposition of $\mathrm{C} 3 \mathrm{~b}$ on target cells enables recognition by $\mathrm{C} 3 \mathrm{~b}$ receptors on phagocytic and antigen-presenting cells. Moreover, the capacity of IgG to activate complement further depends on glycosylation of its Fc segment. For example, IgG can also activate the lectin pathway 


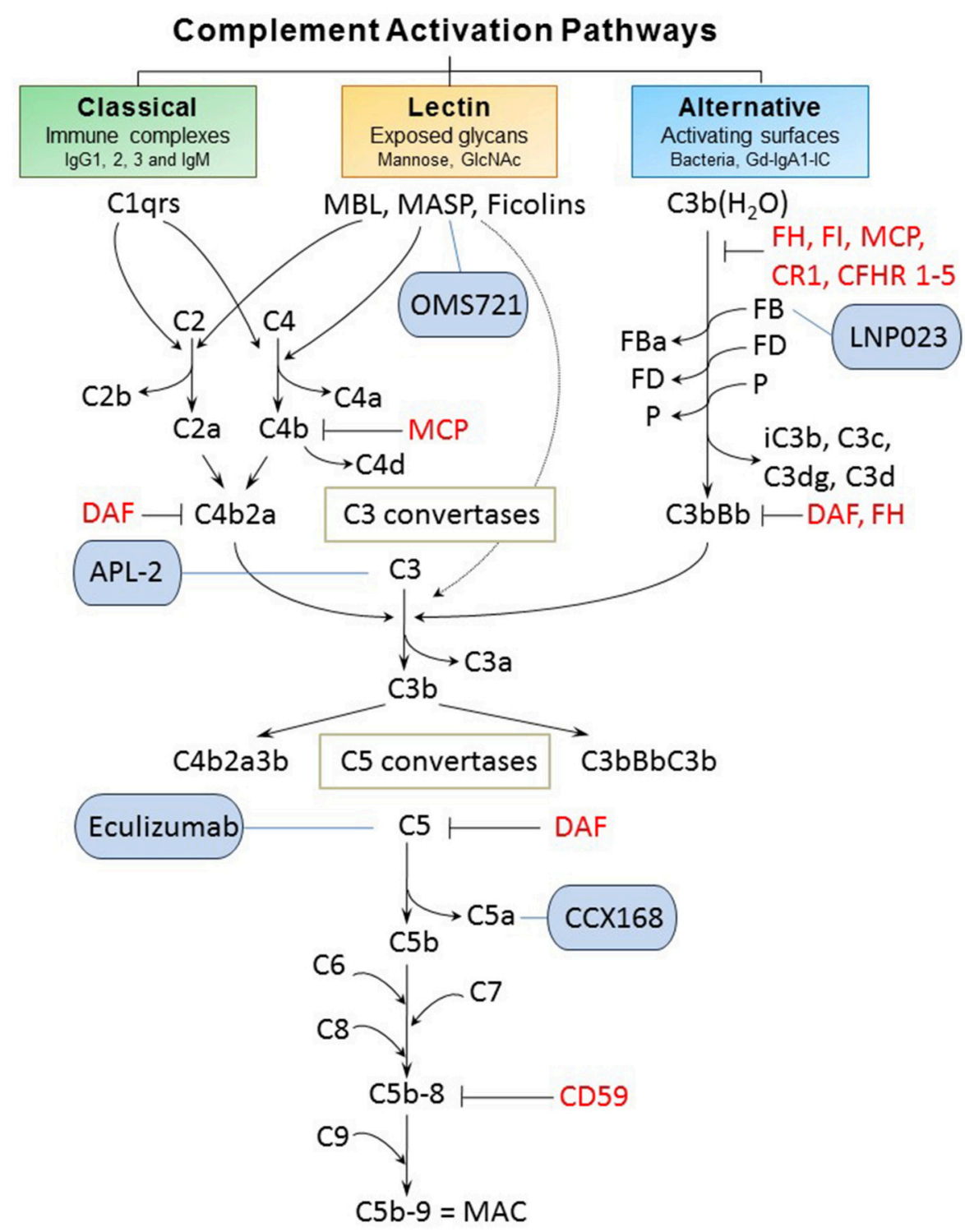

FIGURE 2 | Complement activation pathways and examples of complement-targeting therapeutics for lgAN. The three pathways of complement activation, classical, lectin, and alternative, are initiated by interactions of complement proteins with distinct structures. Complexes of antigen and antibody can activate the classical pathway. Mannan-binding lectin recognizes carbohydrate structures and, upon association with serine proteases (MASP, mannose-associated serine proteases), can activate the lectin pathway. Complement C3 that is covalently bound to microorganism surfaces as C3b initiates the cascade of the alternative pathway. Each pathway can ultimately generate an active C3 convertase, resulting in cleavage of C3 component into C3a and C3b fragments. C3b can interact with C4b2b or $\mathrm{C} 3 \mathrm{bBb}$ to produce $\mathrm{C} 5$ convertase that cleaves $\mathrm{C} 5$ into $\mathrm{C} 5 \mathrm{a}$ and $\mathrm{C} 5 \mathrm{~b}$ fragments. C5b binds to the cell membrane and serves as a platform for assembly of the membrane attack complex (MAC) $(24,25)$. The formation of MAC can be inhibited by membrane-bound CD59 that binds to C8 and/or C9. Several other regulatory proteins of the complement-activation pathways are shown in red. Five complement-targeting therapeutics are shown in blue rounded rectangles. These reagents include two monoclonal antibodies (eculizumab that blocks cleavage of C5; OMS721 targeting MASP-2 that inhibits its protease activity), a C5a receptor antagonist (CCX168), a low-molecular-weight inhibitor of factor B (LNP023), and an inhibitor of C3 activation (APL-2). CR1, complement receptor 1; CFHR 1-5, complement factor $\mathrm{H}$-related proteins 1-5; DAF, decay-accelerating factor; FB, factor B; FD, factor D; Fl, factor I; Gd-IgA1, galactose-deficient IgA1; Gd-IgA1-IC, galactose-deficient IgA1-containing immune complexes; MCP, membrane cofactor protein; P, properdin.

if the Fc glycans consist of complex $N$-glycans with terminal $N$-acetylglucosamine (i.e., galactose-deficient $N$-glycans) (51).

In contrast to IgG and IgM, human IgA does not activate complement in the fluid phase and is considered anti-inflammatory. However, differential IgA glycosylation of monomeric and polymeric $\operatorname{IgA}$ bound in immune complexes may positively or negatively impact complement activation (52). Mouse models have shown that autoantibodies can activate the alternative pathway and induce cell lysis and tissue damage or target autologous complement components. Such autoantibodies 
may play a role in several diseases, especially vascular diseases (53). A passive mouse model of IgAN that uses pre-formed immune complexes comprised of human Gd-IgA1 and human IgG autoantibody specific for Gd-IgA1 induces hematuria and proteinuria; moreover, the glomeruli exhibit mesangial hypercellularity and deposits of IgG, IgA1, and C3 (14).

Activation of the complement system by immune complexes is less well-understood. The relative representation of immunoglobulin isotypes in an immune complex may codetermine which complement pathway or pathways are activated (54). This finding may arm researchers with tools and approaches for use in complement modulation with therapeutics (55). Selected examples relevant for IgAN are shown in Figure 2.

\section{COMPLEMENT PROTEINS AND COMPLEMENT FRAGMENTS IN PATHOLOGY \\ Presence of Complement Elements in Glomeruli}

A characteristic immunofluorescence-microscopy feature of IgAN renal biopsies is the almost universal glomerular deposition of some complement proteins with IgA. C3 is the most abundant, found in up to $90 \%$ of cases (56-60). C3 co-deposits could also be considered a biomarker of actual IgAN in comparison to isolated IgA deposition without renal injury. Interestingly, a European necropsy study from 753 deaths due to suicide or violent deaths (excluding persons with secondary forms of IgAN) found asymptomatic IgA deposition in the kidneys of $6.9 \%$ of individuals (61). Of those, only 4 were C3-positive (0.5\%). A study from Japan evaluated the prevalence of IgA deposition among 510 kidney donors whose renal allografts were biopsied at the time of implantation. The frequency of subclinical IgA deposition was $16.1 \%$, with concomitant C3 deposition reported in 16 individuals (3\%) (62). These studies show that complement activation may distinguish isolated from nephritogenic IgA deposition. Notably, the intensity of C3 deposition by immunofluorescence studies can be influenced by genetic variations in the complement-encoding genes. Patients with at least one allele for a large deletion in the genes encoding CFHR proteins $(\triangle C F H R 3,1)$ have less glomerular immunofluorescence staining for C3 compared to individuals with two wild-type alleles (63).

Apart from C3, other complement elements can be codeposited with IgA. The presence of FH or properdin, suggesting activation of the alternative pathway, has been frequently found in mesangial areas of IgAN patients $(59,64,65)$. More recently, mass-spectrometric analysis of micro-dissected glomeruli from IgAN kidney-biopsy specimens showed significant amounts of $\mathrm{C} 3$ and $\mathrm{C} 5$ as well as all of the complement elements located downstream from the activation cascade (C6 to C9) when compared to biopsies of normal kidneys (66). This result confirms the presence of C5b-9 in IgAN glomeruli, as shown in early immunostaining-based studies $(64,67,68)$. The most important point from this study is the accumulation of alternative-pathway regulation proteins, such as $\mathrm{FH}$, and also CFHR 1,2,3, and 5. Moreover, using targeted proteomic profiling, a reduced abundance of complement receptor 1 (CR1) was detected in biopsy specimens from IgAN patients with progressive vs. non-progressive disease $(66,69)$.

The lectin pathway is activated in some patients with IgAN (70). This subset of patients exhibits mesangial deposition of C4d, MBL, MBL-associated serine proteases (MASPs) 1 and 2 and Lficolin (70). In a large multi-center Spanish cohort of 283 IgAN patients, C4d deposition was found in $38 \%$ of cases (71).

Hallmarks of classical pathway activation, such as $\mathrm{C} 1 \mathrm{q}$, are usually not detected in the glomeruli of patients with IgAN (57), although it may be found in biopsies with advanced glomerulosclerosis (72). Therefore, the presence of glomerular C4d in IgAN suggests activation of the lectin pathway rather than the classical pathway.

\section{Association of Complement Protein Deposition With Disease Severity and Prognosis}

The intensity of mesangial C3 deposition has been negatively correlated with renal survival in a retrospective study of 343 Korean IgAN patients (58). A trend toward a similar finding was reported in a large study of French patients, although the finding did not reach statistical significance (63). The prognostic implications of detection of early (C3b, C3c, iC3b) vs. late (C3d) proteolytic products in mesangial deposits remain matters of debate. One study reported more active disease associated with C3c deposition compared to C3d (73). Another recent study found $\mathrm{C} 3 \mathrm{~d}$ and $\mathrm{C} 3 \mathrm{c} / \mathrm{C} 3 \mathrm{~b} / \mathrm{iC} 3 \mathrm{~b}$ were independently associated with progressive disease in a small number of patients (38). C5b-9 deposits have been associated with disease activity in some immunostaining-based studies $(38,74)$. A recent study using a proteomic approach also confirmed that the presence of glomerular complement protein deposition was associated with progressive IgAN (66).

The deposition of regulatory proteins of the alternative pathway has also been related to the activity of IgAN. Patients with progressive disease had more FH and CFHRs 2 and 5 and less CR1 as assessed by mass spectrometry (66). An immunostaining approach very recently confirmed deposition of CFHR1 and CFHR5, with frequency of the finding dependent on disease severity (38). Notably, glomerular deposition of CFHR5 was significantly more frequent in biopsies from 19 patients with progressive IgAN compared to 18 stable counterparts (odds ratio [OR] 13.4 [2.2-66.9]). On the contrary, FH was less frequently deposited (OR 0.1 [0.08-0.87]) with progressive disease. These findings suggest an imbalance between CFHR5 and FH that may accentuate disease severity. Indeed, CFHRs are sequentially similar to $\mathrm{FH}$ and can compete with $\mathrm{FH}$ for $\mathrm{C} 3 \mathrm{~b}$ binding, but lack some regulatory functions. For example, CFHR1, compared to FH, lacks FI cofactor activity and the capacity to accelerate decay of C3 convertase. CFHR5 can act as FI cofactor but only at supra-physiologic concentrations, thus being less efficient than FH. Nevertheless, the promising results of these early studies need to be confirmed in larger cohorts. 
The deposition of lectin pathway elements has been associated with poorer outcomes in IgAN in several studies. MBL deposits, found in about $25-35 \%$ of patients, have been associated with higher proteinuria, lower eGFR, and more severe histopathological lesions $(70,75)$. Several retrospective studies have confirmed the deleterious prognostic impact of mesangial C4d deposition on renal survival $(71,76,77)$. In those series, the prevalence of $\mathrm{C} 4 \mathrm{~d}$ positivity ranged from $21 \%$ in the pediatric cohort up to $38 \%$ in the adult Spanish cohort $(71,76,77)$.

Mesangial co-deposition of complement elements highlights the pathophysiological role of activation of the alternative and lectin pathways in IgAN and can be considered to be a biomarker of the disease itself as well as its severity. The complexity of the combinations of those deposited proteins offers a potential approach to personalize complement-targeting therapies for patients in the future.

\section{COMPLEMENT FRAGMENTS IN THE CIRCULATION OF IgAN PATIENTS}

Despite the presence of normal or elevated C3 levels in the circulation of most Caucasian patients with IgAN, C3 activation fragments are present in about $50 \%$ of patients (78). Subsequently, larger studies showed that $45 \%$ of the patients with IgAN had a significantly elevated C3dg level (79) and 70\% of pediatric IgAN patients had significantly elevated $\mathrm{C} 3 \mathrm{~d} / \mathrm{C} 3$ ratio in the circulation (80).

Two groups examined plasma levels of activated C3 (actC3) using somewhat similar monoclonal antibodies that detected neoantigens expressed after activation of C3 $(81,82)$. These monoclonal antibodies were produced in the laboratories of highly accomplished complement investigators, Drs. Eberhard (Scripps) and Götze (Göttingen). The neoantigen recognized by the Scripps antibody is on $\mathrm{iC} 3 \mathrm{~b}, \mathrm{C} 3 \mathrm{dg}$, and C3d (83), while the Göttingen antibody recognized C3b, iC3b, C3dg, and C3d (81). Data generated from use of the Scripps antibody are available only for subjects with systemic lupus erythematosus (SLE) (84). Neither antibody appears to be available today.

ActC3 in plasma was detected on one occasion for $73 \%$ of 55 adult and $57 \%$ of 28 pediatric German patients with IgAN when compared to healthy controls (82). When compared to patients with non-immune renal diseases, an elevated plasma actC3 level was found in $30 \%$ of patients with IgAN (82). There was an association with progressive loss of renal function with a single elevated actC3 level, with $75 \%$ sensitivity and $89 \%$ specificity for predicting progression. Weak, but significant, correlations were shown for degree of proteinuria and microscopic hematuria. In a subsequent study of an expanded cohort, mean plasma C3a level was higher for patients with IgAN compared to healthy controls, but mean levels for patients with stable renal function or progressive disease were similar (85). Plasma actC3 levels were near normal for the US patients with normal or minimal mesangial changes, likely corresponding to an Oxford score of M0, E0, S0, T0, and C0 (81). Patients with mesangial proliferation, crescents, or segmental glomerulosclerosis had elevated levels compared to healthy adult controls (81). Plasma
C3a levels were significantly elevated for $35 \%$ of 46 adult patients with IgAN or IgA vasculitis with nephritis (86). In this study, the plasma C3a level was significantly associated with serum creatinine concentration but not 24 -h urinary protein excretion. In the expanded German cohort cited above, the mean plasma C3a level was higher in adult patients with IgAN as compared to healthy controls (85). In this study, plasma C3a level did not correlate with the plasma actC3 level and the mean level did not differ between patients with stable renal function or progressive dysfunction. These findings suggest that the plasma C3a level does not supplant the plasma actC3 level for predicting decline in renal function.

Prior to the delineation of the MBL pathway $(87,88)$, fragments generated by activation of $\mathrm{C} 4$ were considered evidence of activation of the classical pathway. As noted above, we now understand that, for patients with IgAN, they are more likely generated through the MBL pathway. Significant elevation of plasma $\mathrm{C} 4 \mathrm{~d} / \mathrm{C} 4$ ratio was found on at least one occasion for $28 \%$ of adult and $11 \%$ of pediatric patients with IgAN (80). C4-C3 complexes, assumed to indicate activation of the classical pathway, were elevated in only $8 \%$ of patients with IgAN (82).

In two early studies, soluble C5b-9 levels were normal for pediatric and adult patients with $\operatorname{IgAN}(81,82)$. However, another study reported significantly elevated plasma C5b-9 levels for $17 \%$ of adult patients with IgAN (79).

Serum complement levels have also been investigated as diagnostic tools. In a Japanese study including 418 healthy individuals, and 195 IgAN and 111 non-IgAN glomerular disease patients, the pre-biopsy ratio of serum IgA to C3 (IgA/C3) was highest among IgAN patients. Additionally, it was a good diagnostic marker to distinguish IgAN from other glomerular diseases. The higher serum IgA/C3 ratio in IgAN patients compared to that in non-IgAN glomerular disease patients was driven by not only a significantly lower C3 level but also a significantly higher IgA level (89). Several studies from East Asia also suggest that the IgA/C3 ratio can be used as a prognostic marker, with higher values being associated with more severe disease histology (90) and worse clinical outcomes including urinary protein excretion, hematuria, and higher creatinine level (91). Among Japanese patients treated with corticosteroids and tonsillectomy, a higher IgA/C3 ratio was associated with a higher incidence of disease recurrence (92).

\section{Complement Proteins and IgA-Containing Immune Complexes in IgAN}

In IgAN, the presence of IgA-containing circulating immune complexes (93-97) and association of complement-containing immune complexes with disease activity have been observed in early studies, (98-101) with many of these observations clarified in follow-up studies, as detailed in the section above. It is now thought that the pathogenic IgA1-containing immune complexes, that can activate primary human mesangial cells in culture to proliferate and produce cytokines and extracellular matrix, play a key role in the pathogenesis of IgAN (19, 33, 96, 102-109). Moreover, studies of various animal models 
of IgAN also indicate complement involvement in disease development $(14,110)$.

Analysis of a model of immune complexes, heat-aggregated mixture of human $\operatorname{IgG}$ and $\operatorname{IgA} 1$, indicated that these mixedimmunoglobulin aggregates, but not IgA alone, activated C3 (111). Moreover, a study of IgA immune complexes formed in vitro from Gd-IgA1 and anti-glycan IgG antibodies in cord-blood serum indicated that the capacity of these complexes to activate proliferation of mesangial cells was dependent on a heat-sensitive serum factor, presumably complement (112). This model of formation of immune complexes in vitro was later enhanced by using recombinant Gd-IgA1-specific IgG derived from an IgAN patient $(7,112)$. Notably, these immune complexes, when formed in the presence of serum, also activate cultured primary human mesangial cells $(102,104,105,113)$.

C3 is present in IgA1-containing circulating immune complexes of patients with IgAN (114). A pilot study of IgA1-containing circulating immune complexes from IgAN patients as well as those formed in vitro indicated the presence of C3 products (115). Specifically, C3 $\alpha$ and $\beta$ chains were detected in the active, large-molecularmass immune complexes consisting of galactose-deficient IgA1 and recombinant IgG autoantibody. Targeted mass spectrometric analysis identified $\mathrm{iC} 3 \mathrm{~b}, \mathrm{C} 3 \mathrm{c}$, and $\mathrm{C} 3 \mathrm{dg}$ fragments in these complexes. Together, these findings are suggestive of direct binding of $\mathrm{C} 3$ and activation of the alternative pathway in this in vitro model of IgAN immune complexes $(14,35)$.

\section{GENETIC STUDIES ON THE ROLE OF COMPLEMENT PROTEINS IN IgAN}

Genetic influences in the development of IgAN were first implicated by a 1985 study of a familial form of this disease (15). Although more studies followed [e.g., $(116,117)]$, a better appreciation of the impact had to wait until technical advances in genomics enabled genome-wide association studies (GWAS). GWAS of IgAN then provided the initial insight into the genetic architecture of IgAN by identifying specific susceptibility loci across cohorts from Europe, North America and East Asia (118-125). Common genetic variants (including those affecting the alternative complement pathway) may in part explain the geographical differences in disease prevalence worldwide (126). Serum levels of the autoantigen, Gd-IgA1, represent a heritable trait $(127,128)$ and two loci encoding a specific glycosylation enzyme and its chaperone are linked to this phenotype based on two recent GWAS publications $(129,130)$. A reader interested in more details on GWAS studies and genetics of IgAN is referred to more specialized reviews [e.g., (126, 131-135)]. Here, we will briefly present genetic and genomic data related to the role of complement in the pathogenesis of IgAN.

Among the loci associated with IgAN that are related to complement are single-nucleotide polymorphisms (SNPs) on chromosome 1q32 (centered on reference SNP ID number [rs] rs6677604) and 16p11 (rs11574637 and rs7190997). The locus on chromosome 1q32 includes a cluster of genes (CFHR 15) that encode factor $\mathrm{H}$-related proteins and rs6677604 is a surrogate marker of $C F H R 1,3$ gene deletion $(C F H R 3,1 \triangle)$. This allele is associated with a reduced risk of developing IgAN. As CFHR peptides are involved in the regulation of the alternative pathway, the absence of these CFHR peptides may lead to a more potent inhibition of complement system by $\mathrm{FH}$. This postulate is supported by a recent study; it showed that CFHR3,1 $\triangle$ (heterozygous or homozygous) was associated with a reduced level of glomerular immune deposits (IgA, IgG, and C3) (63). These findings correspond well with the early observations about the involvement of the complement system in $\operatorname{IgAN}(35,99)$ and the current understating of complement's role in IgAN (34, 136). Moreover, several studies confirmed that genetic variants in CFH, CFHR3,1, and possibly CFHR5, can differentially affect complement activation and, thus, impact predisposition to IgAN $(34,37,137)$. For example, serum $\mathrm{CFH}$ levels are negatively associated with mesangial C3 deposition (37). For CFHR5, 28 rare and 4 common variants in amino-acid sequence were identified in a Chinese cohort and the distribution of rare variants in patients with IgAN differed significantly from that in controls (137). Moreover, some of the rare variants were functional, as shown by the reduced or increased C3b binding by recombinant CFHR5 variant proteins compared to the wild-type protein.

The second IgAN GWAS locus related to complement is on chromosome 16p11 that contains ITGAM and ITGAX genes that encode integrins $\alpha \mathrm{M}$ and $\alpha \mathrm{X}$, respectively. These integrins have roles in the formation of leukocyte-specific complement receptors 3 and 4 by combining with the integrin $\beta 2$ chain. ITGAM gene product, also known as CD11b, is the $\alpha$-chain of the $\alpha M \beta 2$ integrin. This leukocyte-specific integrin regulates cell activation and adhesion of neutrophils and monocytes, enabling endothelium stimulation and phagocytosis of complementcoated particles. This locus is associated with several other autoimmune diseases, including SLE $(138,139)$. The SLEassociated variant is related to a reduced clearance of immune complexes (140). $\alpha$-X chain protein associates with $\beta 2$-chain to form another leukocyte-specific integrin with functions thought to be similar to those of ITGAM.

Together, recent GWAS have currently identified 22 IgANassociated loci. Within these loci are genes encoding products involved in complement regulation and interaction with immune complexes that may account for these associations with IgAN. These findings have provided novel insights about possible mechanisms of disease. Follow-up genetic and biochemical studies are needed to delineate the precise roles of these complement-associated genes and their alleles.

\section{COMPLEMENT SYSTEM AS TARGET FOR FUTURE THERAPIES}

Recent scientific advances have improved our understanding of the role of complement in the pathogenesis of IgAN. This information has led to identification of new potential therapeutic targets to halt or slow the disease course. So far, 

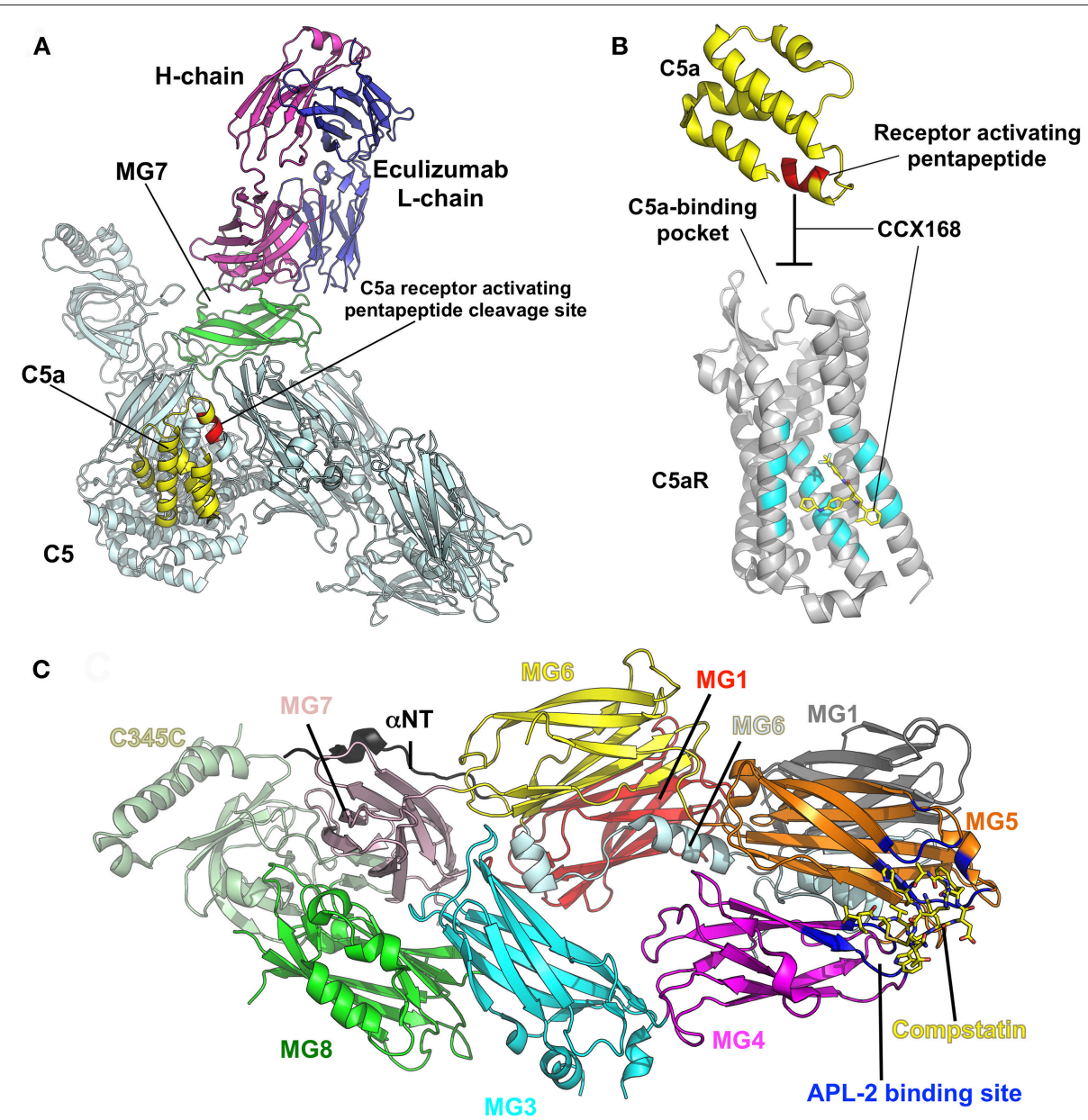

FIGURE 3 | Examples of therapeutic control of complement-activation pathways. (A) The complex of C5 and the Fab derived from eculizumab antibody (PDB ID: $5 \mid 5 K)(145)$ are shown in cartoon model with the heavy $(H)$ and light $(L)$ chains of the Fab colored in magenta and blue, respectively. $C 5$ is shaded in pale cyan, while macroglobulin domain 7 (MG7), the site of eculizumab binding on C5, is highlighted in green. C5a is yellow and the C5a-receptor-activating pentapeptide cleavage site is red. (B) C5a (yellow) binds to the membrane-associated C5a receptor (C5aR, gray background) via the C-terminal C5a pentapeptide (red). CCX168 (Avacopan, yellow stick model) binds to the surface of C5aR (pocket shaded in cyan), thereby blocking C5a binding through allosteric effects on the C5a-binding pocket. The C5a/C5aR model is based on PDB ID: 6C1R (146). (C) Compstatin, and APL-2 are inhibitors of activation of C3. The crystal structure of C3c (PDB ID: 2QKI) (147), a major proteolytic fragment of $\mathrm{C} 3$, is shown in complex with compstatin (yellow stick model). Both inhibitors bind to a site (shaded in blue) formed by the macroglobulin domains 4 and 5 (MG4, MG5). All illustrations were prepared with PyMOL (148).

treatment with complement inhibitors is limited to a few published cases reporting the use of eculizumab, a humanized monoclonal antibody that inhibits cleavage of $\mathrm{C} 5$ by $\mathrm{C} 5$ convertase, as rescue therapy. The first report came from Sweden; a young 16-year-old white male with biopsy-proven crescentic IgAN had failed to respond to corticosteroids and mycophenolate but stabilized when treated with eculizumab, although the therapeutic effects were not sustained (141). Similarly, another 16-year-old male with crescentic IgAN who had failed treatment with corticosteroids, cyclophosphamide, and plasma exchange subsequently had transient improvement in renal function with eculizumab (142). Knowing the role of complement in IgAN pathophysiology, and encouraged by these anecdotal therapeutic results, Herzog et al. used eculizumab as a rescue therapy in a 28 -year-old male with post-transplant recurrent crescentic IgAN. The attempt to salvage the allograft failed but therapy was instituted after the initiation of dialysis and hence may have been too late (143). In a series of elegant experiments, Zhang et al. showed that antagonists of the receptors for C3 and C5 prevented proliferation of cultured human mesangial cells stimulated by IgA and reduced up-regulation of IL- 6 and monocyte chemoattractant protein 1 (MCP-1) (144). In an experimental model of IgAN, mice deficient for C3 and C5 receptors had less proteinuria, mesangial IgA deposition, mesangial matrix expansion and hypercellularity than normal mice, but serum creatinine and blood urea nitrogen levels were similar. These experiments suggest that perhaps inhibition of receptors for C3 and C5 may be promising therapeutic interventions in the future (144). 
Elucidating the role of activation of the MBL and alternative pathways in the pathophysiology of IgAN has identified new potential treatment targets. While some therapies (such as eculizumab and CCX168) may be non-specific inhibitors of the distal common pathway, others target a specific pathway more proximally (Figure 2). Inhibition of complement activation can be achieved with monoclonal antibodies, small molecules, and short peptides that block protein-complex formation and/or enzymatic activity. Eculizumab, a monoclonal humanized antibody, binds to complement protein C5 at the level of macroglobulin domain 7 (MG7), thus blocking cleavage of C5 by C5 convertase into pro-inflammatory components $\mathrm{C} 5 \mathrm{a}$ and C5b (Figure 3A). C5a binds to the membrane-associated C5a receptor $(\mathrm{C} 5 \mathrm{aR})$ via the $\mathrm{C}$-terminal $\mathrm{C} 5 \mathrm{a}$ pentapeptide. CCX168 (Avacopan), a small molecule antagonist of the inflammatory response, binds to the surface of $\mathrm{C} 5 \mathrm{aR}$, thereby blocking $\mathrm{C} 5 \mathrm{a}$ binding through allosteric effects on the C5a-binding pocket (Figure 3B). Compstatin, a cyclic tridecapeptide, and APL-2, a pegylated derivative of compstatin, inhibit the activation of C3 (Figure 3C). MASP-2 complement control protein (CCP) domain binds to $\mathrm{C} 4$. Upon association with MASP-2, C4 undergoes a conformational change whereby the scissile bondcontaining R-loop is inserted into the catalytic site of the serine-protease domain. Cleavage yields fragments $\mathrm{C} 4 \mathrm{a}$ and C4b. Monoclonal antibody OMS721 binds to a CCP domain of MASP-2, inhibiting the lectin pathway by blocking complex formation (Figure 4A). In the alternative pathway, FB binds to $\mathrm{C} 3 \mathrm{~b}$ displacing the $\mathrm{N}$-terminal CCP domains. This in turn leads to rearrangement of the central helices and release of the scissile bond for proteolytic activation (Figure 4B). LNP023, an orally available small molecule, interferes with the alternative complement cascade by inhibition of the proteolytic activity of FB.

To date, clinical trials in the treatment of IgAN using surrogate end-points, such as doubling of serum creatinine, have been limited due to the variable course and often slowly progressing nature of the disease. The size and cost of such trials has been relatively prohibitive so far. More recently, and with guidance from the Unites States Food and Drug Administration, there has been renewed interest in testing novel therapies using "reasonably likely" surrogate end-points (such as quantitative proteinuria) that could lead to accelerated conditional drug approval (151). This change in policy has sparked the initiation of multiple clinical trials evaluating the benefits of various inhibitors of the complement cascade in IgAN (Table 1). Besides evaluating their efficacy, we need to assess the risks associated with the use of these drugs, infections being the primary concern. Very limited data regarding the safety of these inhibitors are available in the literature. In part, our understanding about the risks of drugs that interfere with the complement system comes from syndromes of congenital complement deficiencies. Observations that the infection rates in these children decreases as they age suggest that the role of the innate immunity becomes less prominent in the setting of maturing adaptive immunity (152). The risk of infection also depends on the level of pathway inhibition. While C5 inhibitors increase primarily the risk of neisserial infections, C3

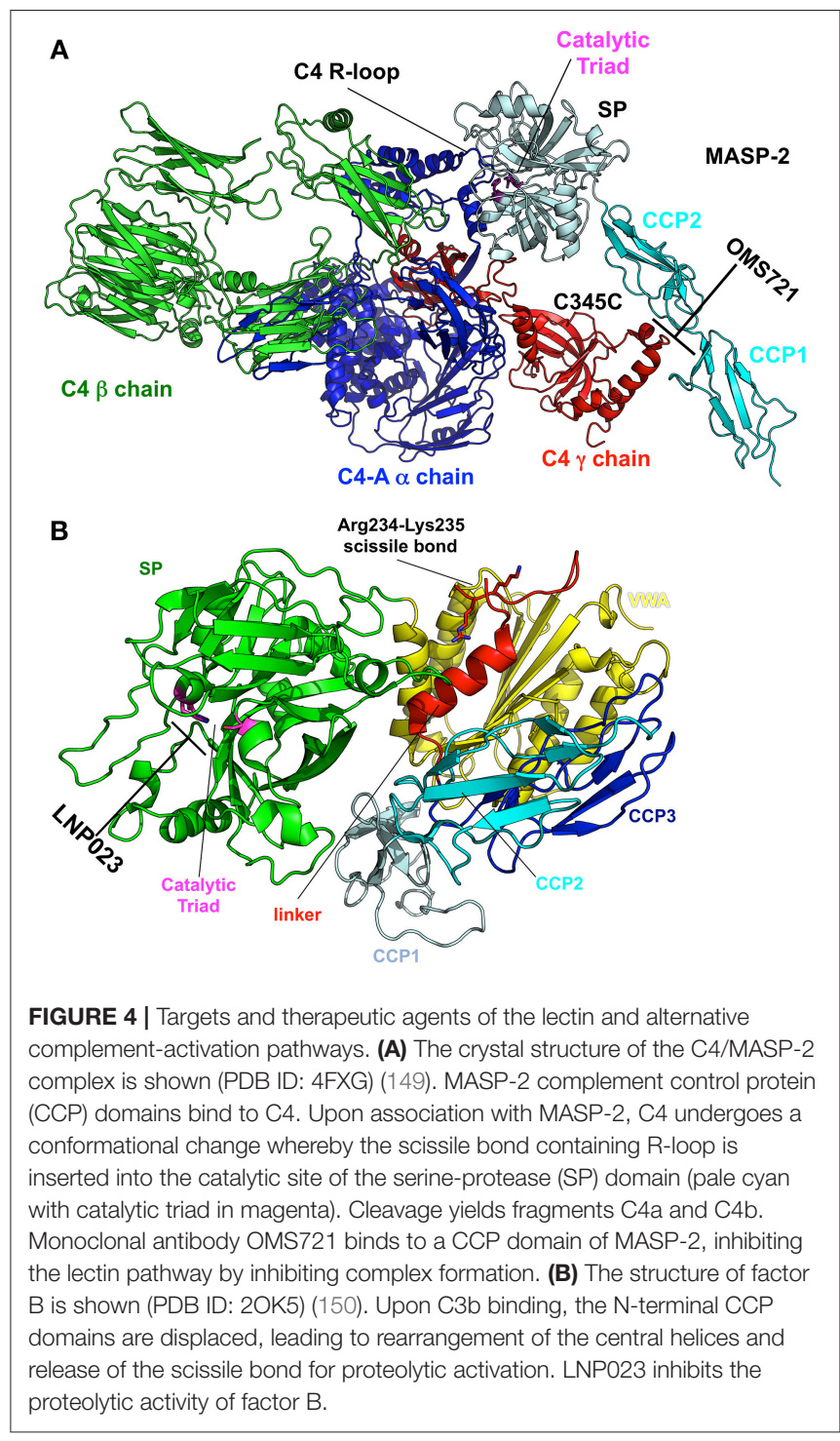

inhibitors are likely to confer a broader infectious susceptibility warranting vaccination against several encapsulated organisms. However, even inhibitors like compstatin do not completely abrogate complement-mediated immunity against pathogens as even modest residual complement activity seems to be protective (55). Other theoretical safety concerns come from the observation that some classical complement deficiencies increase the risk of developing SLE, hence raising the concern for developing autoimmunity with complement inhibition (55). Perhaps the most information about drug safety comes from the use of eculizumab treatment that substantially increases the risk of infections with encapsulated organisms. In particular, the rate of meningococcal infection increases by 1,000 -fold compared to that in the general population. It is recommended that patients contemplating treatment with eculizumab receive meningococcal vaccine at least 2 weeks prior to therapy initiation. Vaccination has reduced the risk of meningitis by 10 -fold. If therapy is initiated prior to 2 
TABLE 1 | Registered clinical trials of complement inhibitors being tested for the treatment of patients with IgAN.

\begin{tabular}{|c|c|c|c|c|c|c|}
\hline Drug & Type & Target & Trial & ID & Phase & Sponsor \\
\hline APL-2 & Inhibitor & C3 & $\begin{array}{l}\text { Phase } 2 \text { study assessing safety and efficacy of } \\
\text { APL-2 in glomerulopathies }\end{array}$ & NCT03453619 & 2 & $\begin{array}{l}\text { Apellis Pharmaceuticals } \\
\text { LLC. }\end{array}$ \\
\hline CCX168 & $\begin{array}{l}\text { Receptor } \\
\text { antagonist }\end{array}$ & $\begin{array}{l}\text { C5a } \\
\text { receptor }\end{array}$ & $\begin{array}{l}\text { Open-label study to evaluate safety and } \\
\text { efficacy of CCX168 in subjects with IgAN on } \\
\text { stable RAAS blockade }\end{array}$ & NCT02384317 & 2 & ChemoCentryx \\
\hline LNP023 & Inhibitor & Factor B & $\begin{array}{l}\text { Study of the safety and efficacy of LNP023 in } \\
\text { patients with kidney disease caused by } \\
\text { inflammation }\end{array}$ & NCT03373461 & 2 & $\begin{array}{l}\text { Novartis } \\
\text { Pharmaceuticals }\end{array}$ \\
\hline \multirow[t]{2}{*}{ OMS721 } & $\mathrm{mAb}$ & MASP-2 & $\begin{array}{l}\text { Safety study of IgAN, lupus nephritis, } \\
\text { membranous nephropathy and C3 } \\
\text { glomerulopathy including dense deposit } \\
\text { disease treated with OMS721 }\end{array}$ & NCT02682407 & 2 & Omeros Corporation \\
\hline & & & $\begin{array}{l}\text { Study of the safety and efficacy of OMS721 in } \\
\text { patients with IgAN }\end{array}$ & NCT03608033 & 3 & \\
\hline
\end{tabular}

Data from https://ClinicalTrials.gov, accessed on December 2, 2018. IgAN, IgA nephropathy;

RAAS, renin angiotensin aldosterone system;

ID-ClinicalTrials.gov identifier.

weeks from the time of vaccination, antibacterial prophylaxis is recommended (153). Ultimately, the duration and extent of complement inhibition will also play a role in the safety of treatment. Several of these therapeutic agents are also being evaluated in a variety of other disorders ranging from atypical hemolytic uremic syndrome to age-related macular degeneration to various glomerulonephritides such as lupus nephritis and membranous nephropathy. The cumulative experience from all these trials will inform our future use of complement inhibitors in IgAN.

\section{CONCLUSION}

In the past several decades, much progress has been made in understanding the role of the complement system in IgAN pathogenesis and prognosis. Data from studies of the pathology features, biochemistry of $\operatorname{IgA} 1$, and genetic influences on the disease and animal models confirm the involvement of the alternative and lectin pathways. Markers of complement activation are not only diagnostic but are also emerging as prognostic tools to risk-stratify disease severity. Complement components likely play significant roles in amplifying the

\section{REFERENCES}

1. Berger J, Hinglais N. Intercapillary deposits of IgA-IgG. J Urol Nephrol. (1968) 74:694-5.

2. Berthoux FC, Mohey H, Afiani A. Natural history of primary IgA nephropathy. Semin Nephrol. (2008) 28:4-9. doi: 10.1016/j.semnephrol.2007.10.001

3. Hastings MC, Bursac Z, Julian BA, Villa Baca E, Featherston J, Woodford SY, et al. Life expectancy for patients from the southeastern united states with IgA nephropathy. Kidney Int Rep. (2018) 3:99-104. doi: 10.1016/j.ekir.2017.08.008

4. Jennette JC. The immunohistology of IgA nephropathy. Am J Kidney Dis. (1988) 12:348-52. doi: 10.1016/S0272-6386(88)80022-2 inflammatory response for formation of immune complexes and their deposition in the glomerular mesangium. These findings have sparked marked interest in targeting the complement cascade at multiple levels in an effort to halt or slow the disease progression. Much remains to be learned about the optimal timing and intensity of use of complement inhibitors and their efficacy and safety in the treatment of patients with IgAN.

\section{AUTHOR CONTRIBUTIONS}

DR, JN, BJ, and RW conceived the general outline. BK and TG generated the figures, with feedback from JN, DR, and BJ. All authors (DR, NM, BJ, BK, TG, JN, RW) contributed intellectually by writing assigned sections, editing and revising the drafts, and proofreading the manuscript.

\section{FUNDING}

The authors were supported in part by grants from the National Institutes of Health DK078244 and DK082753, and a gift from IGA Nephropathy Foundation of America.

5. Conley ME, Cooper MD, Michael AF. Selective deposition of immunoglobulin A1 in immunoglobulin a nephropathy, anaphylactoid purpura nephritis, and systemic lupus erythematosus. J Clin Invest. (1980) 66:1432-6. doi: 10.1172/JCI109998

6. Suzuki H, Kiryluk K, Novak J, Moldoveanu Z, Herr AB, Renfrow MB, et al. The pathophysiology of IgA nephropathy. J Am Soc Nephrol. (2011) 22:1795-803. doi: 10.1681/ASN.2011050464

7. Suzuki H, Fan R, Zhang Z, Brown R, Hall S, Julian BA, et al. Aberrantly glycosylated IgAl in IgA nephropathy patients is recognized by IgG antibodies with restricted heterogeneity. J Clin Invest. (2009) 119:1668-77. doi: 10.1172/JCI38468

8. Launay P, Grossetete B, Arcos-Fajardo M, Gaudin E, Torres SP, Beaudoin L, et al. Fca receptor (CD89) mediates the development of immunoglobulin 
A (IgA) nephropathy (Berger's disease). Evidence for pathogenic soluble receptor-Ig complexes in patients and CD89 transgenic mice. J Exp Med. (2000) 191:1999-2009. doi: 10.1084/jem.191.11.1999

9. Allen AC, Bailey EM, Brenchley PE, Buck KS, Barratt J, Feehally J. Mesangial IgA1 in IgA nephropathy exhibits aberrant $O$-glycosylation: observations in three patients. Kidney Int. (2001) 60:969-73. doi: 10.1046/j.1523-1755.2001.060003969.x

10. Hiki Y, Odani H, Takahashi M, Yasuda $Y$, Nishimoto A, Iwase $\mathrm{H}$, et al. Mass spectrometry proves under-O-glycosylation of glomerular IgA1 in IgA nephropathy. Kidney Int. (2001) 59:1077-85. doi: 10.1046/j.1523-1755.2001.0590031077.x

11. Aucouturier P, Monteiro RC, Noel LH, Preud'homme JL, Lesavre P. Glomerular and serum immunoglobulin $G$ subclasses in IgA nephropathy. Clin Immunol Immunopathol. (1989) 51:338-47. doi: 10.1016/0090-1229(89)90032-9

12. Ponticelli C, Glassock RJ. Posttransplant recurrence of primary glomerulonephritis. Clin J Am Soc Nephrol. (2010) 5:2363-72. doi: $10.2215 /$ CJN.06720810

13. Saha MK, Julian BA, Novak J, Rizk DV. Secondary IgA nephropathy. Kidney Int. (2018) 94:674-81. doi: 10.1016/j.semnephrol.2007.10.004

14. Knoppova B, Reily C, Maillard N, Rizk DV, Moldoveanu Z, Mestecky J, et al. The origin and activities of IgA1-containing immune complexes in IgA nephropathy. Front Immunol. (2016) 7:117. doi: 10.1016/j.kint.2018.02.030

15. Julian BA, Quiggins PA, Thompson JS, Woodford SY, Gleason K, Wyatt RJ. Familial IgA nephropathy. Evidence of an inherited mechanism of disease. $N$ Engl J Med. (1985) 312:202-8. doi: 10.1056/NEJM198501243120403

16. Ehrlich P, Morgenroth J. Zur Theorie der Lysenwirkung. Berlin Klin Woch. (1899) 36:6-9.

17. Kaufmann SH. Immunology's foundation: the 100-year anniversary of the nobel prize to paul ehrlich and elie metchnikoff. Nat Immunol. (2008) 9:705-12. doi: 10.1038/ni0708-705

18. Hajishengallis G, Reis ES, Mastellos DC, Ricklin D, Lambris JD. Novel mechanisms and functions of complement. Nat Immunol. (2017) 18:128898. doi: 10.1038/ni.3858

19. Nesargikar PN, Spiller B, Chavez R. The complement system: history, pathways, cascade and inhibitors. Eur J Microbiol Immunol. (2012) 2:103-11. doi: 10.1556/EuJMI.2.2012.2.2

20. Ricklin D, Hajishengallis G, Yang K, Lambris JD. Complement: a key system for immune surveillance and homeostasis. Nat Immunol. (2010) 11:785-97. doi: 10.1038/ni.1923

21. Bajic G, Degn SE, Thiel S, Andersen GR. Complement activation, regulation, and molecular basis for complement-related diseases. EMBO J. (2015) 34:2735-57. doi: 10.15252/embj.201591881

22. Ricklin D, Reis ES, Lambris JD. Complement in disease: a defence system turning offensive. Nat Rev Nephrol. (2016) 12:383-401. doi: 10.1038/nrneph.2016.70

23. Wouters D, Zeerleder S. Complement inhibitors to treat IgMmediated autoimmune hemolysis. Haematologica. (2015) 100:1388-95. doi: 10.3324/haematol.2015.128538

24. Floege J, Daha MR. IgA nephropathy: new insights into the role of complement. Kidney Int. (2018) 94:16-8. doi: 10.1016/j.kint.2018. 03.009

25. Kemper C, Pangburn MK, Fishelson Z. Complement nomenclature 2014. Mol Immunol. (2014) 61:56-8. doi: 10.1016/j.molimm.2014.07.004

26. Noris M, Remuzzi G. Overview of complement activation and regulation. Semin Nephrol. (2013) 33:479-92. doi: 10.1016/j.semnephrol.2013.08.001

27. Almitairi JOM, Venkatraman Girija U, Furze CM, Simpson-Gray X, Badakshi F, Marshall JE, et al. Structure of the C1r-C1s interaction of the C1 complex of complement activation. Proc Natl Acad Sci USA. (2018) 115:768-73. doi: 10.1073/pnas.1718709115

28. Gaboriaud C, Thielens NM, Gregory LA, Rossi V, Fontecilla-Camps JC, Arlaud GJ. Structure and activation of the C1 complex of complement: unraveling the puzzle. Trends Immunol. (2004) 25:368-73. doi: 10.1016/j.it.2004.04.008

29. Dobo J, Kocsis A, Gal P. Be on target: strategies of targeting alternative and lectin pathway components in complement-mediated diseases. Front Immunol. (2018) 9:1851. doi: 10.3389/fimmu.2018. 01851
30. Merle NS, Church SE, Fremeaux-Bacchi V, Roumenina LT. Complement system part I - molecular mechanisms of activation and regulation. Front Immunol. (2015) 6:262. doi: 10.3389/fimmu.2015.00262

31. Pangburn MK, Schreiber RD, Muller-Eberhard HJ. Formation of the initial $\mathrm{C} 3$ convertase of the alternative complement pathway. Acquisition of C3blike activities by spontaneous hydrolysis of the putative thioester in native C3. J Exp Med. (1981) 154:856-67. doi: 10.1084/jem.154.3.856

32. Yaseen S, Demopulos G, Dudler T, Yabuki M, Wood CL, Cummings WJ, et al. Lectin pathway effector enzyme mannan-binding lectin-associated serine protease-2 can activate native complement $\mathrm{C} 3$ in absence of $\mathrm{C} 4$ and/or $\mathrm{C} 2$. FASEB J. (2017) 31:2210-9. doi: 10.1096/fj.201601306R

33. Coppo R, Amore A, Gianoglio B, Porcellini MG, Peruzzi L, Gusmano R, et al. Macromolecular IgA and abnormal IgA reactivity in sera from children with IgA nephropathy. Italian collaborative paediatric IgA nephropathy study. Clin Nephrol. (1995) 43:1-13.

34. Maillard N, Wyatt RJ, Julian BA, Kiryluk K, Gharavi A, Fremeaux-Bacchi V, et al. Current understanding of the role of complement in IgA nephropathy. J Am Soc Nephrol. (2015) 26:1503-12. doi: 10.1681/ASN.2014101000

35. Wyatt RJ, Kanayama Y, Julian BA, Negoro N, Sugimoto S, Hudson EC, et al. Complement activation in IgA nephropathy. Kidney Int. (1987) 31:1019-23.

36. McRae JL, Cowan PJ, Power DA, Mitchelhill KI, Kemp BE, Morgan BP, et al. Human factor H-related protein 5 (FHR-5). A new complement-associated protein. J Biol Chem. (2001) 276:6747-54. doi: 10.1074/jbc.M007495200

37. Zhu L, Zhai YL, Wang FM, Hou P, Lv JC, Xu DM, et al. Variants in complement factor $\mathrm{H}$ and complement factor $\mathrm{H}$-related protein genes, CFHR3 and CFHR1, affect complement activation in IgA nephropathy. J Am Soc Nephrol. (2015) 26:1195-204. doi: 10.1681/ASN.2014010096

38. Medjeral-Thomas NR, Lomax-Browne HJ, Beckwith H, Willicombe M, McLean AG, Brookes P, et al. Circulating complement factor H-related proteins 1 and 5 correlate with disease activity in IgA nephropathy. Kidney Int. (2017) 92:942-52. doi: 10.1016/j.kint.2017.03.043

39. Tortajada A, Gutierrez E, Goicoechea de Jorge E, Anter J, Segarra A, Espinosa $\mathrm{M}$, et al. Elevated factor $\mathrm{H}$-related protein 1 and factor $\mathrm{H}$ pathogenic variants decrease complement regulation in IgA nephropathy. Kidney Int. (2017) 92:953-63. doi: 10.1016/j.kint.2017.03.041

40. Cook EM, Lindorfer MA, van der Horst H, Oostindie S, Beurskens FJ, Schuurman J, et al. Antibodies that efficiently form hexamers upon antigen binding can induce complement-dependent cytotoxicity under complement-limiting conditions. J Immunol. (2016) 197:1762-75. doi: 10.4049/jimmunol.1600648

41. Dekkers G, Rispens T, Vidarsson G. Novel concepts of altered immunoglobulin G galactosylation in autoimmune diseases. Front Immunol. (2018) 9:553. doi: 10.3389/fimmu.2018.00553

42. Dekkers G, Treffers L, Plomp R, Bentlage AEH, de Boer M, Koeleman CAM, et al. Decoding the human immunoglobulin G-glycan repertoire reveals a spectrum of Fc-receptor- and complement-mediated-effector activities. Front Immunol. (2017) 8:877. doi: 10.3389/fimmu.2017.00877

43. Hadzhieva M, Pashov AD, Kaveri S, Lacroix-Desmazes S, Mouquet H, Dimitrov JD. Impact of antigen density on the binding mechanism of IgG antibodies. Sci Rep. (2017) 7:3767. doi: 10.1038/s41598-017-03942-z

44. Lee CH, Romain G, Yan W, Watanabe M, Charab W, Todorova B, et al. IgG Fc domains that bind $\mathrm{C} 1 \mathrm{q}$ but not effector $\mathrm{Fc} \gamma$ receptors delineate the importance of complement-mediated effector functions. Nat Immunol. (2017) 18:889-98. doi: 10.1038/ni.3770

45. Peschke B, Keller CW, Weber P, Quast I, Lunemann JD. Fc-Galactosylation of human immunoglobulin gamma isotypes improves $\mathrm{Clq}$ binding and enhances complement-dependent cytotoxicity. Front Immunol. (2017) 8:646. doi: 10.3389/fimmu.2017.00646

46. Rowley TF, Peters SJ, Aylott M, Griffin R, Davies NL, Healy LJ, et al. Engineered hexavalent $\mathrm{Fc}$ proteins with enhanced $\mathrm{Fc}$-gamma receptor avidity provide insights into immune-complex interactions. Commun Biol. (2018) 1:146. doi: 10.1038/s42003-018-0149-9

47. Spirig R, Campbell IK, Koernig S, Chen CG, Lewis BJB, Butcher R, et al. rIgG1 Fc hexamer inhibits antibody-mediated autoimmune disease via effects on complement and FcyRs. J Immunol. (2018) 200:2542-53. doi: 10.4049/jimmunol.1701171

48. van den Bremer ET, Beurskens FJ, Voorhorst M, Engelberts PJ, de Jong RN, van der Boom BG, et al. Human IgG is produced in a pro-form that requires 
clipping of C-terminal lysines for maximal complement activation. MAbs. (2015) 7:672-80. doi: 10.1080/19420862.2015.1046665

49. Vidarsson G, Dekkers G, Rispens T. IgG subclasses and allotypes: from structure to effector functions. Front Immunol. (2014) 5:520. doi: 10.3389/fimmu.2014.00520

50. Diebolder CA, Beurskens FJ, de Jong RN, Koning RI, Strumane K, Lindorfer MA, et al. Complement is activated by IgG hexamers assembled at the cell surface. Science. (2014) 343:1260-3. doi: 10.1126/science.1248943

51. Quast I, Lunemann JD. Fc glycan-modulated immunoglobulin $\mathrm{G}$ effector functions. J Clin Immunol. (2014) 34(Suppl 1):S51-5. doi: 10.1007/s10875-014-0018-3

52. Oortwijn BD, Roos A, Royle L, van Gijlswijk-Janssen DJ, Faber-Krol MC, Eijgenraam JW, et al. Differential glycosylation of polymeric and monomeric IgA: a possible role in glomerular inflammation in IgA nephropathy. J Am Soc Nephrol. (2006) 17:3529-39. doi: 10.1681/ASN.2006040388

53. Daha NA, Banda NK, Roos A, Beurskens FJ, Bakker JM, Daha MR, et al. Complement activation by (auto-) antibodies. Mol Immunol. (2011) 48:1656-65. doi: 10.1016/j.molimm.2011.04.024

54. Noris M, Remuzzi G. Genetics of immune-mediated glomerular diseases: focus on complement. Semin Nephrol. (2017) 37:447-63. doi: 10.1016/j.semnephrol.2017.05.018

55. Ricklin D, Mastellos DC, Reis ES, Lambris JD. The renaissance of complement therapeutics. Nat Rev Nephrol. (2018) 14:26-47. doi: 10.1038/nrneph.2017.156

56. Evans DJ, Williams DG, Peters DK, Sissons JG, Boulton-Jones JM, Ogg CS, et al. Glomerular deposition of properdin in Henoch-Schönlein syndrome and idiopathic focal nephritis. Br Med J. (1973) 3:326-8.

57. Katafuchi R, Nagae H, Masutani K, Tsuruya K, Mitsuiki K. Comprehensive evaluation of the significance of immunofluorescent findings on clinicopathological features in IgA nephropathy. Clin Exp Nephrol. (2019) 23:169-81. doi: 10.1007/s10157-018-1619-6

58. Kim SJ, Koo HM, Lim BJ, Oh HJ, Yoo DE, Shin DH, et al. Decreased circulating C3 levels and mesangial C3 deposition predict renal outcome in patients with IgA nephropathy. PLoS ONE. (2012) 7:e40495. doi: 10.1371/journal.pone.0040495

59. Miyazaki R, Kuroda M, Akiyama T, Otani I, Tofuku Y, Takeda R. Glomerular deposition and serum levels of complement control proteins in patients with IgA nephropathy. Clin Nephrol. (1984) 21:335-40.

60. Wyatt RJ. The complement system in IgA nephropathy and HenochSchönlein purpura: functional and genetic aspects. Contrib Nephrol. (1993) 104:82-91. doi: 10.1159/000422400

61. Varis J, Rantala I, Pasternack A, Oksa H, Jantti M, Paunu ES, et al. Immunoglobulin and complement deposition in glomeruli of 756 subjects who had committed suicide or met with a violent death. J Clin Pathol. (1993) 46:607-10.

62. Suzuki K, Honda K, Tanabe K, Toma H, Nihei H, Yamaguchi Y. Incidence of latent mesangial IgA deposition in renal allograft donors in Japan. Kidney Int. (2003) 63:2286-94. doi: 10.1046/j.1523-1755.63.6s.2.x

63. Jullien P, Laurent B, Claisse G, Masson I, Dinic M, Thibaudin D, et al. Deletion variants of CFHR1 and CFHR3 associate with mesangial immune deposits but not with progression of IgA nephropathy. J Am Soc Nephrol. (2018) 29:661-9. doi: 10.1681/ASN.2017010019

64. Rauterberg EW, Lieberknecht HM, Wingen AM, Ritz E. Complement membrane attack (MAC) in idiopathic IgA-glomerulonephritis. Kidney Int. (1987) 31:820-9. doi: 10.1038/ki.1987.72

65. Tomino Y, Sakai H, Nomoto Y, Endoh M, Arimori S, Fujita T. Deposition of C4-binding protein and $\beta 1 \mathrm{H}$ globulin in kidneys of patients with IgA nephropathy. Tokai J Exp Clin Med. (1981) 6:217-22.

66. Paunas TIF, Finne K, Leh S, Marti HP, Mollnes TE, Berven F, et al. Glomerular abundance of complement proteins characterized by proteomic analysis of laser-captured microdissected glomeruli associates with progressive disease in IgA nephropathy. Clin Proteom. (2017) 14:30. doi: 10.1186/s12014-017-9165-x

67. Alexopoulos E, Papaghianni A, Papadimitriou M. The pathogenetic significance of C5b-9 in IgA nephropathy. Nephrol Dial Transplant. (1995) 10:1166-72. doi: 10.1093/ndt/10.7.1166

68. Falk RJ, Dalmasso AP, Kim Y, Tsai CH, Scheinman JI, Gewurz H, et al. Neoantigen of the polymerized ninth component of complement.
Characterization of a monoclonal antibody and immunohistochemical localization in renal disease. J Clin Invest. (1983) 72:560-73.

69. Moll S, Miot S, Sadallah S, Gudat F, Mihatsch MJ, Schifferli JA. No complement receptor 1 stumps on podocytes in human glomerulopathies. Kidney Int. (2001) 59:160-8. doi: 10.1046/j.1523-1755.2001. 00476.x

70. Roos A, Rastaldi MP, Calvaresi N, Oortwijn BD, Schlagwein N, van GijlswijkJanssen DJ, et al. Glomerular activation of the lectin pathway of complement in IgA nephropathy is associated with more severe renal disease. J Am Soc Nephrol. (2006) 17:1724-34. doi: 10.1681/ASN.2005090923

71. Espinosa M, Ortega R, Sanchez M, Segarra A, Salcedo MT, Gonzalez F, et al. Association of C4d deposition with clinical outcomes in IgA nephropathy. Clin J Am Soc Nephrol. (2014) 9:897-904. doi: 10.2215/CJN.09710913

72. Lee HJ, Choi SY, Jeong KH, Sung JY, Moon SK, Moon JY, et al. Association of C1q deposition with renal outcomes in IgA nephropathy. Clin Nephrol. (2013) 80:98-104. doi: 10.5414/CN107854

73. Nakagawa H, Suzuki S, Haneda M, Gejyo F, Kikkawa R. Significance of glomerular deposition of C3c and C3d in IgA nephropathy. Am J Nephrol. (2000) 20:122-8. doi: 10.1159/000013568

74. Stangou M, Alexopoulos E, Pantzaki A, Leonstini M, Memmos D. C5b-9 glomerular deposition and tubular $\alpha 3 \beta 1$-integrin expression are implicated in the development of chronic lesions and predict renal function outcome in immunoglobulin A nephropathy. Scand J Urol Nephrol. (2008) 42:373-80. doi: $10.1080 / 00365590801943241$

75. Liu Z, Xu B, Nameta M, Zhang Y, Magdeldin S, Yoshida Y, et al. Profiling of kidney vascular endothelial cell plasma membrane proteins by liquid chromatography-tandem mass spectrometry. Clin Exp Nephrol. (2013) 17:327-37. doi: 10.1007/s10157-012-0708-1

76. Fabiano RCG, de Almeida Araujo S, Bambirra EA, Oliveira EA, Simoes ESAC, Pinheiro SVB. Mesangial C4d deposition may predict progression of kidney disease in pediatric patients with IgA nephropathy. Pediatr Nephrol. (2017) 32:1211-20. doi: 10.1007/s00467-017-3610-y

77. Wagrowska-Danilewicz M, Danilewicz M. The utility of glomerular C4d immunostaining in renal biopsies in patients with immunoglobulin A nephropathy. a clinicopathological study. Pol J Pathol. (2017) 68:148-52. doi: 10.5114/pjp.2017.69691

78. Solling J. Circulating immune complexes and complement breakdown product C3d in glomerulonephritis and kidney transplantation. Acta Pathol Microbiol Immunol Scand C. (1984) 92:213-20.

79. Brenchley PE, Coupes B, Short CD, O’Donoghue DJ, Ballardie FW, Mallick NP. Urinary C3dg and C5b-9 indicate active immune disease in human membranous nephropathy. Kidney Int. (1992) 41:933-7. doi: 10.1038/ki.1992.143

80. Tanaka C, Suhara Y, Kikkawa Y. [Circulating immune complexes and complement breakdown products in childhood IgA nephropathy]. Nihon Jinzo Gakkai Shi. (1991) 33:709-17.

81. Wyatt RJ, Julian BA. Activation of complement in IgA nephropathy. Am J Kidney Dis. (1988) 12:437-42. doi: 10.1016/S0272-6386(88)80042-8

82. Zwirner J, Burg M, Schulze M, Brunkhorst R, Götze O, Koch KM, et al. Activated complement C3: a potentially novel predictor of progressive IgA nephropathy. Kidney Int. (1997) 51:1257-64.

83. Tamerius JD, Pangburn MK, Muller-Eberhard HJ. Detection of a neoantigen on human C3bi and C3d by monoclonal antibody. J Immunol. (1985) 135:2015-9.

84. Negoro N, Okamura M, Takeda T, Koda S, Amatsu K, Inoue T, et al. The clinical significance of $\mathrm{iC} 3 \mathrm{~b}$ neoantigen expression in plasma from patients with systemic lupus erythematosus. Arthritis Rheum. (1989) 32:1233-42.

85. Janssen U, Bahlmann F, Kohl J, Zwirner J, Haubitz M, Floege J. Activation of the acute phase response and complement C3 in patients with IgA nephropathy. Am J Kidney Dis. (2000) 35:21-8. doi: 10.1016/S0272-6386(00)70296-4

86. Abou-Ragheb HH, Williams AJ, Brown CB, Milford-Ward A. Plasma levels of the anaphylatoxins $\mathrm{C} 3 \mathrm{a}$ and $\mathrm{C} 4 \mathrm{a}$ in patients with IgA nephropathy/Henoch-Schonlein nephritis. Nephron. (1992) 62:22-6. doi: $10.1159 / 000186989$

87. Ikeda K, Sannoh T, Kawasaki N, Kawasaki T, Yamashina I. Serum lectin with known structure activates complement through the classical pathway. J Biol Chem. (1987) 262:7451-4. 
88. Thiel S, Vorup-Jensen T, Stover CM, Schwaeble W, Laursen SB, Poulsen K, et al. A second serine protease associated with mannan-binding lectin that activates complement. Nature. (1997) 386:506-10.

89. Tomino Y, Suzuki S, Imai H, Saito T, Kawamura T, Yorioka N, et al. Measurement of serum IgA and C3 may predict the diagnosis of patients with IgA nephropathy prior to renal biopsy. J Clin Lab Anal. (2000) 14:220-3. doi: 10.1002/1098-2825(2000)14:5\%3C220::AID-JCLA4\%3E3.0.CO;2-2

90. Komatsu H, Fujimoto S, Hara S, Sato Y, Yamada K, Eto T. Relationship between serum IgA/C3 ratio and progression of IgA nephropathy. Intern Med. (2004) 43:1023-8. doi: 10.2169/internalmedicine.43.1023

91. Kawasaki Y, Maeda R, Ohara S, Suyama K, Hosoya M. Serum IgA/C3 and glomerular C3 staining predict severity of IgA nephropathy. Pediatr Int. (2018) 60:162-7. doi: 10.1111/ped.13461

92. Hirano K, Amano H, Kawamura T, Watanabe K, Koike K, Shimizu A, et al. Tonsillectomy reduces recurrence of IgA nephropathy in mesangial hypercellularity type categorized by the Oxford classification. Clin Exp Nephrol. (2016) 20:425-32. doi: 10.1007/s10157-015-1170-7

93. Lesavre P, Digeon M, Bach JF. Analysis of circulating IgA and detection of immune complexes in primary IgA nephropathy. Clin Exp Immunol. (1982) 48:61-9.

94. McPhaul JJ, Jr. IgA-associated glomerulonephritis. Annu Rev Med. (1977) 28:37-42. doi: 10.1146/annurev.me.28.020177.000345

95. Tomana M, Matousovic K, Julian BA, Radl J, Konecny K, Mestecky J. Galactose-deficient IgA1 in sera of IgA nephropathy patients is present in complexes with IgG. Kidney Int. (1997) 52:509-16. doi: 10.1038/ki. 1997.361

96. Tomana M, Novak J, Julian BA, Matousovic K, Konecny K, Mestecky J. Circulating immune complexes in IgA nephropathy consist of IgA1 with galactose-deficient hinge region and antiglycan antibodies. J Clin Invest. (1999) 104:73-81. doi: 10.1172/JCI5535

97. Woodroffe AJ, Gormly AA, McKenzie PE, Wootton AM, Thompson AJ, Seymour AE, et al. Immunologic studies in IgA nephropathy. Kidney Int. (1980) 18:366-74

98. Coppo R, Amore A, Roccatello D, Amoroso A, Maffei S, Quattrocchio G, et al. Complement receptor (CR1) and IgG or IgA on erythrocytes and in circulating immune complexes in patients with glomerulonephritis. Nephrol Dial Transplant. (1989) 4:932-8.

99. Coppo R, Basolo B, Martina G, Rollino C, De Marchi M, Giacchino F, et al. Circulating immune complexes containing $\operatorname{IgA}$, IgG and $\operatorname{IgM}$ in patients with primary IgA nephropathy and with Henoch-Schoenlein nephritis. Correlation with clinical and histologic signs of activity. Clin Nephrol. (1982) 18:230-9.

100. Coppo R, Basolo B, Piccoli G, Mazzucco G, Bulzomi MR, Roccatello D, et al. IgA1 and IgA2 immune complexes in primary IgA nephropathy and Henoch-Schönlein nephritis. Clin Exp Immunol. (1984) 57:583-90.

101. Roccatello D, Picciotto G, Ropolo R, Coppo R, Quattrocchio G, Cacace $\mathrm{G}$, et al. Kinetics and fate of IgA-IgG aggregates as a model of naturally occurring immune complexes in IgA nephropathy. Lab Invest. (1992) 66:86-95.

102. Novak J, Barratt J, Julian BA, Renfrow MB. Aberrant glycosylation of the IgA1 molecule in IgA nephropathy. Semin Nephrol. (2018) 38:461-76. doi: 10.1016/j.semnephrol.2018.05.016

103. Novak J, Julian BA, Tomana M, Mestecky J. IgA glycosylation and IgA immune complexes in the pathogenesis of IgA nephropathy. Semin Nephrol. (2008) 28:78-87. doi: 10.1016/j.semnephrol.2007.10.009

104. Novak J, Moldoveanu Z, Julian BA, Raska M, Wyatt RJ, Suzuki Y, et al. Aberrant glycosylation of IgA1 and anti-glycan antibodies in $\operatorname{IgA}$ nephropathy: role of mucosal immune system. Adv Otorhinolaryngol. (2011) 72:60-3. doi: 10.1159/000324607

105. Novak J, Raskova Kafkova L, Suzuki H, Tomana M, Matousovic K, Brown R, et al. IgA1 immune complexes from pediatric patients with IgA nephropathy activate cultured human mesangial cells. Nephrol Dial Transplant. (2011) 26:3451-7. doi: 10.1093/ndt/gfr448

106. Novak J, Tomana M, Matousovic K, Brown R, Hall S, Novak L, et al. IgA1-containing immune complexes in IgA nephropathy differentially affect proliferation of mesangial cells. Kidney Int. (2005) 67:504-13. doi: 10.1111/j.1523-1755.2005.67107.x
107. Novak J, Vu HL, Novak L, Julian BA, Mestecky J, Tomana M. Interactions of human mesangial cells with IgA and IgA-containing immune complexes. Kidney Int. (2002) 62:465-75. doi: 10.1046/j.1523-1755.2002.00477.x

108. Placzek WJ, Yanagawa H, Makita Y, Renfrow MB, Julian BA, Rizk DV, et al. Serum galactose-deficient-IgA1 and IgG autoantibodies correlate in patients with IgA nephropathy. PLoS ONE. (2018) 13:e0190967. doi: 10.1371/journal.pone.0190967

109. Roccatello D, Coppo R, Basolo B, Martina G, Rollino C, Cordonnier D, et al. Interaction between the macrophage system and IgA immune complexes in IgA nephropathy. Proc Eur Dial Transplant Assoc. (1983) 20:610-6.

110. Suzuki H, Suzuki Y. Murine models of human IgA nephropathy. Semin Nephrol. (2018) 38:513-20. doi: 10.1016/j.semnephrol.2018. 05.021

111. Waldo FB, Cochran AM. Mixed IgA-IgG aggregates as a model of immune complexes in IgA nephropathy. J Immunol. (1989) 142:3841-6.

112. Yanagihara T, Brown R, Hall S, Moldoveanu Z, Goepfert A, Tomana M, et al. In vitro-generated immune complexes containing galactose-deficient IgA1 stimulate proliferation of mesangial cells. Results Immunol. (2012) 2:166-72. doi: 10.1016/j.rinim.2012.08.002

113. Novak J, Moldoveanu Z, Renfrow MB, Yanagihara T, Suzuki H, Raska M, et al. IgA nephropathy and Henoch-Schoenlein purpura nephritis: aberrant glycosylation of $\operatorname{IgA1}$, formation of IgA1-containing immune complexes, and activation of mesangial cells. Contrib Nephrol. (2007) 157:134-8. doi: $10.1159 / 000102455$

114. Czerkinsky C, Koopman WJ, Jackson S, Collins JE, Crago SS, Schrohenloher $\mathrm{RE}$, et al. Circulating immune complexes and immunoglobulin A rheumatoid factor in patients with mesangial immunoglobulin A nephropathies. J Clin Invest. (1986) 77:1931-8.

115. Maillard N, Boerma L, Hall S, Huang ZQ, Mrug M, Moldoveanu Z et al. Proteomic analysis of engineered IgAl-IgG immune complexes reveals association with activated complement C3. J Am Soc Nephrol. (2013) 24:490A

116. Gharavi AG, Yan Y, Scolari F, Schena FP, Frasca GM, Ghiggeri GM, et al. IgA nephropathy, the most common cause of glomerulonephritis, is linked to 6q22-23. Nat Genet. (2000) 26:354-7. doi: 10.1038/81677

117. Kiryluk K, Julian BA, Wyatt RJ, Scolari F, Zhang H, Novak J, et al. Genetic studies of IgA nephropathy: past, present, and future. Pediatr Nephrol. (2010) 25:2257-68. doi: 10.1007/s00467-010-1500-7

118. Ai Z, Li M, Liu W, Foo JN, Mansouri O, Yin P, et al. Low alphadefensin gene copy number increases the risk for IgA nephropathy and renal dysfunction. Sci Transl Med. (2016) 8:345ra88. doi: 10.1126/scitranslmed.a af2 106

119. Feehally J, Farrall M, Boland A, Gale DP, Gut I, Heath S, et al HLA has strongest association with IgA nephropathy in genome-wide analysis. I Am Soc Nephrol. (2010) 21:1791-7. doi: 10.1681/ASN.20100 10076

120. Gharavi AG, Kiryluk K, Choi M, Li Y, Hou P, Xie J, et al. Genome-wide association study identifies susceptibility loci for IgA nephropathy. Nat Genet. (2011) 43:321-7. doi: 10.1038/ng.787

121. Kiryluk K, Li Y, Sanna-Cherchi S, Rohanizadegan M, Suzuki H, Eitner F, et al. Geographic differences in genetic susceptibility to IgA nephropathy: GWAS replication study and geospatial risk analysis. PLoS Genet. (2012) 8:e1002765. doi: 10.1371/journal.pgen.1002765

122. Kiryluk K, Li Y, Scolari F, Sanna-Cherchi S, Choi M, Verbitsky M, et al. Discovery of new risk loci for IgA nephropathy implicates genes involved in immunity against intestinal pathogens. Nat Genet. (2014) 46:1187-96. doi: $10.1038 /$ ng.3118

123. Li M, Foo JN, Wang JQ, Low HQ, Tang XQ, Toh KY, et al. Identification of new susceptibility loci for IgA nephropathy in Han Chinese. Nat Commun. (2015) 6:7270. doi: 10.1038/ncomms8270

124. Wang W, Li G, Hong D, Zou Y, Fei D, Wang L. Replication of genomewide association study identified seven susceptibility genes, affirming the effect of rs 2856717 on renal function and poor outcome of IgA nephropathy. Nephrology. (2017) 22:811-7. doi: 10.1111/nep.12860

125. Zhou XJ, Qi YY, Hou P, Lv JC, Shi SF, Liu LJ, et al. Cumulative effects of variants identified by genome-wide association studies in IgA nephropathy. Sci Rep. (2014) 4:4904. doi: 10.1038/srep04904 
126. Kiryluk K, Novak J, Gharavi AG. Pathogenesis of immunoglobulin A nephropathy: recent insight from genetic studies. Annu Rev Med. (2013) 64:339-56. doi: 10.1146/annurev-med-041811-142014

127. Gharavi AG, Moldoveanu Z, Wyatt RJ, Barker CV, Woodford SY, Lifton RP, et al. Aberrant IgA1 glycosylation is inherited in familial and sporadic IgA nephropathy. J Am Soc Nephrol. (2008) 19:1008-14. doi: 10.1681/ASN.2007091052

128. Lomax-Browne HJ, Visconti A, Pusey CD, Cook HT, Spector TD, Pickering MC, et al. IgA1 glycosylation is heritable in healthy twins. J Am Soc Nephrol. (2017) 28:64-8. doi: 10.1681/ASN.2016020184

129. Gale DP, Molyneux K, Wimbury D, Higgins P, Levine AP, Caplin B, et al. Galactosylation of IgA1 is associated with common variation in C1GALT1. J Am Soc Nephrol. (2017) 28:2158-66. doi: 10.1681/ASN.2016091043

130. Kiryluk K, Li Y, Moldoveanu Z, Suzuki H, Reily C, Hou P, et al. GWAS for serum galactose-deficient IgA1 implicates critical genes of the O-glycosylation pathway. PLoS Genet. (2017) 13:e1006609. doi: 10.1371/journal.pgen.1006609

131. Foo JN, Liu J, Yu XQ. GWAS reveal novel IgA nephropathy risk loci. Oncotarget. (2015) 6:15738-9. doi: 10.18632/oncotarget.4632

132. Kiryluk K, Novak J. The genetics and immunobiology of IgA nephropathy. $J$ Clin Invest. (2014) 124:2325-32. doi: 10.1172/JCI74475

133. Li M, Yu XQ. Genetic determinants of IgA nephropathy: eastern perspective. Semin Nephrol. (2018) 38:455-60. doi: 10.1016/j.semnephrol.2018.05.015

134. Neugut YD, Kiryluk K. Genetic determinants of IgA nephropathy: western perspective. Semin Nephrol. (2018) 38:443-54. doi: 10.1016/j.semnephrol.2018.05.014

135. Xie J, Shapiro S, Gharavi A. Genetic studies of IgA nephropathy: what have we learned from genome-wide association studies. Contrib Nephrol. (2013) 181:52-64. doi: 10.1159/000348652

136. Hastings MC, Moldoveanu Z, Suzuki H, Berthoux F, Julian BA, Sanders JT, et al. Biomarkers in IgA nephropathy: relationship to pathogenetic hits. Exp Opin Med Diagn. (2013) 7:615-27. doi: 10.1517/17530059.2013.856878.

137. Zhai YL, Meng SJ, Zhu L, Shi SF, Wang SX, Liu LJ, et al. Rare Variants in the complement factor H-related protein 5 Gene contribute to genetic susceptibility to IgA nephropathy. J Am Soc Nephrol. (2016) 27:2894-905. doi: 10.1681/ASN.2015010012

138. Hom G, Graham RR, Modrek B, Taylor KE, Ortmann W, Garnier $\mathrm{S}$, et al. Association of systemic lupus erythematosus with C8orf13BLK and ITGAM-ITGAX. $N$ Engl J Med. (2008) 358:900-9. doi: 10.1056/NEJMoa0707865

139. Ramos PS, Criswell LA, Moser KL, Comeau ME, Williams AH, Pajewski NM, et al. A comprehensive analysis of shared loci between systemic lupus erythematosus (SLE) and sixteen autoimmune diseases reveals limited genetic overlap. PLoS Genet. (2011) 7:e1002406. doi: 10.1371/journal.pgen.1002406

140. Rhodes B, Furnrohr BG, Roberts AL, Tzircotis G, Schett G, Spector TD, et al. The rs1143679 (R77H) lupus associated variant of ITGAM (CD11b) impairs complement receptor 3 mediated functions in human monocytes. Ann Rheum Dis. (2012) 71:2028-34. doi: 10.1136/annrheumdis-2012-201390

141. Rosenblad T, Rebetz J, Johansson M, Bekassy Z, Sartz L, Karpman D. Eculizumab treatment for rescue of renal function in IgA nephropathy. Pediatr Nephrol. (2014) 29:2225-8. doi: 10.1007/s00467-014-2863-y

142. Ring T, Pedersen BB, Salkus G, Goodship TH. Use of eculizumab in crescentic IgA nephropathy: proof of principle and conundrum? Clin Kidney J. (2015) 8:489-91. doi: 10.1093/ckj/sfv076
143. Herzog AL, Wanner C, Amann K, Lopau K. First treatment of relapsing rapidly progressive IgA nephropathy with eculizumab after living kidney donation: a case report. Transplant Proc. (2017) 49:1574-7. doi: 10.1016/j.transproceed.2017.02.044

144. Zhang Y, Yan X, Zhao T, Xu Q, Peng Q, Hu R, et al. Targeting $\mathrm{C} 3 \mathrm{a} / \mathrm{C} 5 \mathrm{a}$ receptors inhibits human mesangial cell proliferation and alleviates immunoglobulin A nephropathy in mice. Clin Exp Immunol. (2017) 189:6070. doi: 10.1111/cei.12961

145. Schatz-Jakobsen JA, Zhang Y, Johnson K, Neill A, Sheridan D, Andersen GR. Structural basis for eculizumab-mediated inhibition of the complement terminal pathway. J Immunol. (2016) 197:337-44. doi: 10.4049/jimmunol.1600280

146. Liu H, Kim HR, Deepak R, Wang L, Chung KY, Fan H, et al. Orthosteric and allosteric action of the C5a receptor antagonists. Nat Struct Mol Biol. (2018) 25:472-81.

147. Janssen BJ, Halff EF, Lambris JD, Gros P. Structure of compstatin in complex with complement component $\mathrm{C} 3 \mathrm{c}$ reveals a new mechanism of complement inhibition. J Biol Chem. (2007) 282:29241-7. doi: 10.1074/jbc.M7045 87200

148. DeLano WL. The PyMOL Molecular Graphics System. (2002). Available online at: http://www.pymol.org/

149. Kidmose RT, Laursen NS, Dobo J, Kjaer TR, Sirotkina S, Yatime L, et al. Structural basis for activation of the complement system by component C4 cleavage. Proc Natl Acad Sci USA. (2012) 109:15425-30. doi: 10.1073/pnas.1208031109

150. Milder FJ, Gomes L, Schouten A, Janssen BJ, Huizinga EG, Romijn RA, et al. Factor B structure provides insights into activation of the central protease of the complement system. Nat Struct Mol Biol. (2007) 14:224-8. doi: $10.1038 / \mathrm{nsmb} 1210$

151. Thompson A, Carroll K, L AI, Floege J, Perkovic V, Boyer-Suavet S, et al. Proteinuria reduction as a surrogate end point in trials of IgA nephropathy. Clin J Am Soc Nephrol. (2019) 14:469-81. doi: 10.2215/CJN.086 00718

152. Ricklin D, Lambris JD. New milestones ahead in complement-targeted therapy. Semin Immunol. (2016) 28:208-22. doi: 10.1016/j.smim.2016.06.001

153. Barnum SR. Therapeutic inhibition of complement: well worth the risk. Trends Pharmacol Sci. (2017) 38:503-5. doi: 10.1016/j.tips.2017. 03.009

Conflict of Interest Statement: DR, BJ, JN are co-founders of Reliant Glycosciences, LLC. The company did not have any role in the drafting of this manuscript. RW has consultation agreements with Omeros Corporation, Apellis Pharmaceuticals, Aduro Biotech, and Catabasis Pharmaceuticals.

The remaining authors declare that the research was conducted in the absence of any commercial or financial relationships that could be construed as a potential conflict of interest.

Copyright (c) 2019 Rizk, Maillard, Julian, Knoppova, Green, Novak and Wyatt. This is an open-access article distributed under the terms of the Creative Commons Attribution License (CC BY). The use, distribution or reproduction in other forums is permitted, provided the original author(s) and the copyright owner(s) are credited and that the original publication in this journal is cited, in accordance with accepted academic practice. No use, distribution or reproduction is permitted which does not comply with these terms. 